\title{
Perempuan Yang Berada di Lapas (Lembaga Pemasyarakatan) Perlu Mengembangkan Mekanisme Koping Efektif
}

\author{
Oleh: Gero Sabina, Batbual Bringiwati \\ (Politehnik Kesehatan Kemenkes Kupang, Prodi Keperawatan \& Kebidanan)
}

Alamat email: bina_gero@yahoo.co.id

\begin{abstract}
Abstrak
Seorang perempuan yang berada di lapas terjadi karena berbagai alasan hukum. Keadaan ini memerlukan adaptasi baik fisik, psikologis, spiritual dan sosial. Adaptasi ini memerlukan mekanisme koping efektif, agar dapat melalui masa sulit di lapas dengan sukses. Tujuan penelitian ini mengeksplorasi pikiran, perasaan dan respon tindakan perempuan yang berada di lapas(penjara) dalam mempertahankan kesehatan jiwa. Penelitian ini menggunakan pendekatan kualitatif, dengan jumlah informan 51 orang perempuan, narapidana di lapas Kelas III Wanita, Oktober 2016. Desain penelitian ekologikal-psikologi dengan studi lapangan, untuk mendeskripsikan bagaimana seorang perempuan mempertahankan kesehatan jiwa selama dalam penjara. Partisipan menulis pikiran, perasaan dan respon tindakan terkait pikiran dan perasaan selama berada di lapas untuk dianalisis. Narapidana perempuan lebih muda mengungkapkan pikiran dan perasaan yang dialami dari pada respon tindakan selama berada di lapas. Perempuan yang mengungkapkan pikirannya 70,6 \%, perasaan 76,5 \% sedang respon tindakan 31,4\%. Semakin mudah seseorang mengungkapkan pikiran, perasaan serta respon tindakan, semakin baik mengetahui pola mekanisme koping. Pikiran, perasaan dan respon tindakan positif hanya sedikit tereksplorasi, pikiran rindu anak, rindu keluarga dan rindu suami ; perasaan rindu rumah, bahagia dan senang; respon tindakan berdoa dan berserah, minta bantuan doa orang lain, berbuat baik kepada teman dan menerima situasi saat ini. Pikiran, perasaan dan respon tindakan seorang perempuan selama di lapas lebih banyak negatif. Oleh karena itu pola koping yang dikembangkan bersifat tidak efektif. Koping yang tidak efektif kurang mampu mempertahankan kesehatan jiwa seseorang.
\end{abstract}

Kata-kata kunci: Perempuan, Lembaga Pemasyarakatan (lapas), dan Mekanisme Koping

\section{PENDAHULUAN}

\section{Latar Belakang}

Berada dalam lapas atau penjara merupakan suatu keadaan yang tidak menyenangkan bagi setiap orang. Penjara menurut Kamus Besar Bahasa Indonesia berarti tempat mengurung orang hukuman, atau disebut bui, atau lembaga pemasyarakatan. Sesuai pengertian ini, seorang dalam penjara itu dikurung, kebebasannya dibatasi oleh aturan karena orang ini sedang menjalani proses rehabilitasi. Lembaga Pemasyarakatan atau lapas adalah tempat untuk melaksanakan pembinaan narapidana dan anak didik Pemasyarakatan (UU Nomor 6 Tahun 2013 
tentang Tata Tertib Lapas dan Rutan). Narapidana merupakan orang terpidana yang menjalani pidana, hilang kemerdekaan di Lapas. Setiap narapidana wajib mematuhi tatatertib lapas. Tatatertib lapas mencakup kewajiban dan larangan. Ada 7(tujuh) kewajiban yaitu mengikuti seluruh kegiatan yang diprogramkan, mengenakan pakaian seragam yang telah ditentukan, dan lain-lain. Larangan meliputi 22 point antara lain dilarang melakukan perbuatan asusila dan /atau penyimpangan seksual, upaya melarikan diri atau membantu pelarian, dan lain-lain.

Menurut konsep keperawatan, manusia terdiri dari dimensi fisik/biologi, psikologi/mental, sosial dan spiritual, dan merupakan satu kesatuan yang holistik dan unik. Seorang didalam penjara mengalami tekanan dan stres psikologi/mental/jiwa yang dapat mengancam kesehatan jiwa. Pengertian kesehatan jiwa menurut UU Nomor 18 tahun 2014 adalah suatu kondisi seorang individu yang dapat berkembang secara fisik, mental, spiritual, dan sosial sehingga individu tersebut menyadari kemampuan sendiri, dapat mengatasi tekanan, dapat bekerja secara produktif, dan mampu memberikan kontribusi untuk komunitasnya. Dari pengertian narapidana dan kesehatan jiwa, dapat disimpulkan bahwa seorang narapidana menghadapi kondisi yang menghambat dirinya untuk berkembang secara fisik, mental, spiritual dan sosial untuk mengembangkan kemampuan, mengatasi tekanan, bekerja produktif dan memberi kontribusi untuk komunitasnya. Suatu paradoks antara pemenuhan kebutuhan kesehatan jiwa sebagai seorang terpidana dengan aturan dan tatatertib di lapas. Komunitas selama di lapas adalah sesama narapidana. Mempertahankan kesehatan jiwa penting diupayakan, selama melewati masa hukuman. Upaya yang utama melalui pengembangan dan pengelolahan mekanisme koping dalam diri dengan efektif.

Mekanisme koping merupakan cara seseorang untuk mempertahankan keseimbangan jiwa/psikologis menghadapi berbagai stres dan tekanan. Bentuk mekanisme koping berupa perilaku tidak sadar untuk memberi perlindungan psikologis terhadap peristiwa yang menegangkan (Potter P. \& Griffin A, 2005). Koping merupakan aktifitas kognitif dan motorik yang dilakukan secara konstan dalam upaya mengatasi tuntutan internal dan eksternal diri yang melelahkan bahkan dapat melebih energy dalam diri. Mekanisme koping membatasi kerusakan atau masalah psikologi diri (Gail W. Stuart. 2006). Koping dapat diidentifikasi melalui respon fisik dan psikologi. Koping yang efektif menghasilkan adaptasi, sedangkan koping yang tidak efektif menyebabkan perilaku maladaptive. Mekanisme koping ego lebih banyak bersifat membohongi diri sendiri terhadap realita yang ada. Mekanisme koping yang kontruktif atau sehat berupa penalaran, objektivitas, konsentrasi, humor, supresi, ambiguitas dan empati. Bentuk penyesuaian diri yang paling baik dibandingkan mekanisme koping konstruktif adalah antisipasi atau kesiapan mental untuk menerima suatu stimulus, afiliasi atau kebutuhan untuk berhubungan dengan orang lain, altruism atau mementingkan kepentingan orang lain, penegasan diri atau mengekspresikan perasaan dan pikiran secara langsung, 
pengamatan diri atau melakukan pengujian diri secara objektif atau instrokspeksi diri (APA, 2016).

Indonesia merupakan urutan ke sepuluh jumlah tahanan terbanyak di dunia. Rasio jumlah tahanan Indonesia berada dalam posisi 180 dengan rasio 67 orang per 100.000 penduduk. Tahanan wanita berada dalam urutan 84. Jumlah populasi penjara bertambah $20 \%$ sejak tahun 2000. Total populasi perempuan sebagai narapidanapun meningkat $50 \%$. Proporsi perempuan dan anak perempuan dalam total populasi penjara perempuan meningkat 5,4\% sejak tahun 2000, dan akhir akhir ini naik menjadi 6, $8 \%$ (www.mantannapi.com). Narapidana di Lapas wanita kelas III Kupang, berjumlah 93 orang. Jumlah ini melebihi kapasitas lapas tersebut atau berjumlah $186 \%$. Keadaan ini menunjukkan banyaknya narapidana perempuan sampai melebihi kapasitas yang tersedia. Jumlah napi yang besar berpotensi terganggunya kenyamanan dan keadaan ini dapat meningkatkan stres para napi perempuan tersebut (Sistem Database Pemasyarakatan, Maret 2017). Tindak pidana yang menyebabkan seorang perempuan masuk lapas antara lain pencurian, pembunuhan, pelanggaran aturan, kejahatan kriminal, penghasutan, penyuapan, penipuan, pemalsuan surat, dan lain-lain.

Lembaga Pemasyarakat menurut pandangan masyarakat adalah tempat buangan orang yang melakukan kejahatan. Berbagai tipe orang dapat saling bertemu di lapas, mereka juga tidak saling mengenal, situasi asing dan serba terbatas dan tidak ada perbedaan antara sesame narapidana. Penelitian Rahmat, 2015, system baru pembinaan narapidana adalah memandang mereka sebagai subyek sekaligus obyek. Sebagai subyek melihat seorang narapidana sebagai mahluk Tuhan dengan keunikan masing-masing. Sebagai obyek seorang narapidana dipandang berbeda dalam pembinaan, sesuai penggolongan yang dibuat di lapas. Dalam lapas setiap narapidana akan dibina, sehingga setelah masa hukumannya selesai, akan keluar menjadi orang baik dan bertanggung jawab, menyadari kesalahannya dan tidak lagi melakukan perbuatan yang melanggar hukum.Perkembangan peradaban manusia, termasuk hak-hak asasi manusia mempengaruhi cara pembinaan narapidana di lapas saat ini. System baru dengan melakukan pengolongan narapidana mempermudah proses pembinaan, karena pembinaan bisa didapat juga dari sesame anggota kelompok.

Orang yang berada di penjara atau lapas bukan orang dengan masalah kejiwaan (ODMK), namun berisiko menjadi ODMK. Oleh karena itu dalam Undang-undang tentang Kesehatan Jiwa, dijelaskan adanya upaya promosi kesehatan di lapas sebagai salah satu target promosi kesehatan jiwa. Lengkapnya dijelaskan dalam pasal 8 , ayat (9) upaya promotif di lingkungan lembaga pemasyarakatan dan rumah tahanan dilaksanakan dalam bentuk: a. peningkatan pengetahuan dan pemahaman warga binaan pemasyarakatan tentang Kesehatan Jiwa; b. pelatihan kemampuan adaptasi dalam masyarakat; dan c. menciptakan suasana kehidupan yang kondusif untuk Kesehatan Jiwa warga binaan pemasyarakatan. 
Lembaga pemasyarakatan khusus perempuan atau wanita mempunyai keunikan tersendiri. Wanita yang menjadi narapidana menjalani hidup yang berbeda dari sebelumnya. Narapidana wanita mengalami banyak kehilangan, antara lain kehilangan anak dan keluarga, kontrol diri, model, dan dukungan. Selain itu, narapidana wanita mengalami kehilangan hubungan dengan lawan jenis, kehilangan hak mendapat pelayanan, hak memiliki barang, kehilangan rasa aman, dan kehilangan lain-lain. Suatu proses kehilangan ini yang memaksa dirinya beradaptasi agar dapat bertahan hidup dalam lingkungan barunya, apalagi untuk masa hukuman dalam kurun waktu tertentu (Meilina Clara Pricilla, 2013) .

\section{Tujuan Penelitian}

Penelitian ini bertujuan mendeskripsikan pikiran, perasaan dan respon tindakan (fisik) sebagai mekanisme koping perempuan penghuni lapas dalam mempertahankan kesehatan jiwa. Tujuan khusus, mengidentifikasi mekanisme koping efektif dan non efektif perempuan penghuni lapas wanita kelas III KupangNusa Tenggara Timur.

\section{METODE PENELITIAN}

Penelitian dengan pendekatan kualitatif, menggunakan metode ekologikal psikologi, melalui studi lapangan. Data diambil dari 51 partisipan (perempuan) melalui observasi dan menulis essay, di lapas wanita kelas III Kupang, NTT, bulan Oktober 2016. Pikiran, perasaan dan respon tindakan dituliskan di kertas, lalu dikumpulkan peneliti. Analisis dilakukan dengan mendaftarkan pikiran, perasaan dan respon tindakan (fisik) partisipan tersebut, memilah tema-tema dari pikiran, perasaan dan respon tindakan atas yang positif dan negatif. Menganalisis dengan cara membandingkan antara tema-tema positif, negatif dari pikiran, perasaan dan repson tindakan dengan teori tentang mekanisme koping.

\section{HASIL PENELITIAN}

Data terkumpul saat peneliti melakukan pengabdian kepada masyarakat di lapas tersebut. Observasi dan lembar essay tes yang sudah diisi oleh 51 partisipan, dikategorikan menjadi tema-tema pikiran, perasaan dan respon tindakan yang positif dan negatif sebagai berikut.

Tabel 1. Pikiran (positif dan negatif) Partisipan Lapas Wanita Kelas III Kupang, NTT, Tahun 2016

\begin{tabular}{|l|l|}
\hline \multicolumn{1}{|c|}{ Tema Pikiran Positif } & \multicolumn{1}{c|}{ Tema Pikiran Negatif } \\
\hline Ingat/memikirkan anak : 16 & Sidang terus ditunda, belum terima keputusan: 2 \\
Rindu suasana rumah: 2 & Keluarga ada yang sakit
\end{tabular}


Rindu suami: 7

Rindu keluarga: 8

Senang dengan teman yang bersifat terbuka

Ingin pulang rumah: 2

Berserah kepada Tuhan
Tidak berjumpa anak dan orang tua

Tidak bisa telpon: 2

Tidak di besuk suami : 2

Tidak bisa baca dan tulis

Tidak ada uang

Tidak bertemu keluarga karena situasi \&kondisi

Mama lagi sakit

Memikirkan pidana : lama vonis hukuman yg akan dijalani

Teman sudah bebas dirinya belum

Istirahat makan telur, ikan asin, terung makanan yg sdh dimakan bertahun tahun

Mempunyai beban berat

Marah pada suami: "gara-gara suami dihukuman 8 tahun"

Tidak pernah dikunjungi keluarga suami dan saya

Semua yg terjadi bertolak belakang dg apa yg diinginkan

Banyak pikiran karena jauh dari keluarga

Anak tak pernah kunjung/besuk : 2

Diperalat atasan, tidak dibantu

Berpikir kapan keluar dari masalah

Pekerjaan setelah keluar dari penjara

Timbah air got

Analisis:

Pikiran positif seorang perempuan yang berada di lapas yang pertama memikirkan anaknya, keluarga dan suami. Suasana rumah dan ingin pulang rumah mendapat perhatian pula. Berserah kepada Tuhan mendapat urutan terakhir dan hanya ditulis oleh seorang narapidana. Narapidana tersebut menulis dirinya berpikir untuk selalu berpasrah kepada Tuhan dan meningkatkan doa pribadi. Pikiran negatif terbanyak antara lain tentang sidang yang terus ditunda sehingga belum ada keputusan, tidak bisa menelpon dan anak yang tidak pernah mengunjungi atau melihat ibunya.

Tabel 2. Perasaan (positif dan negatif) Partisipan Lapas Wanita Kelas III Kupang, NTT, Tahun 2016

\begin{tabular}{|l|l|}
\hline Tema Perasaan Positif & \multicolumn{1}{|c|}{ Tema Perasaan Negatif } \\
\hline Bahagia /senang & Stres dan stres menghadapi saksi : 10 \\
Rindu rumah : 2 & Tidak tenang, tidak senang, tidak nyaman: 6 \\
& ketakutan luar biasa menghadapi vonis hukuman $: 4$ \\
& Sakit hati ketika dihina, dimarah, difitnah $: 2$ \\
& Pemerintah tak adil (tak dpt PB=pembebasan \\
& bersyarat) $: 2$ \\
& Jenuh \\
& Malas \\
& Jengkel, benci $: 8$ \\
& Bosan $: 2$ \\
\hline
\end{tabular}


Tuhan tidak adil

Tidak berguna bagi keluarga

Komunitas penjara buat rasa sakit

Sedih : 9

Kecewa : 4

Marah : 2

Cemas

Analisis: Perasaan positif utama partisipan adalah rindu rumah dan bahagia serta senang. Perasaan negatif paling banyak menulis dirinya stres, sedih, jengkel/benci, tidak tenang, tidak senang, tidak nyaman dan kecewa. Perasaan didominasi oleh perasaan negatif.

Tabel 3. Respon tindakan (positif dan negatif) Partisipan Lapas Wanita

Kelas III Kupang, NTT, Tahun 2016

\begin{tabular}{|l|l|}
\hline \multicolumn{1}{|c|}{ Respon Tindakan Positif } & \multicolumn{1}{c|}{ Respon Tindakan Negatif } \\
\hline Bertemu anak & Banyak diam \\
Bertemu bapa-mama & Marah-marah : 4 \\
Pasrah menghadapi situasi saat ini & Diam \\
Berbuat baik dengan teman & Cuek \\
Minta bantuan doa dari orang lain & Menangis \\
Berdoa dan berserah kepada Tuhan & Menyendiri \\
& Mudah tersinggung \\
& Mengeluh cuaca panas: 2 \\
& Tidak nyaman \\
& Tidak terima kalau di perintah \\
& Sakit kepala dan leher tegang \\
& Tidak tahan menghadapi situasi penjara \\
& Susah tidur \\
\hline
\end{tabular}

Analisis: Partisipan lebih mampu mengungkapkan respon tindakan negatif dari pada respon tindakan positif. Tindakan negatif utama adalah marah-marah dan mengeluh cuaca panas. Tindakan positif bertemu anak, orang tua, pasrah menghadapi situasi saat ini, berbuat baik dengan teman, meminta bantuan doa dari orang lain, berdoa dan berserah kepada Tuhan.

\section{PEMBAHASAN}

Mengerti tentang stres dan koping penting untuk dapat mengembangkan pendidikan kesehatan, promosi, dan mencegahan penyakit. Stress dapat menyebabkan sakit secara langsung yang berdampak pada fisik atau tidak langsung melalui perilaku mal-adaptif (merokok, miras, narkoba dll). Stres tidak sama mempengaruhi seseorang, mengelolah koping diri secara baik menyebab seseorang tidak mengalami sakit. Pola koping seseorang berbeda menghadapi setiap situasi hidup. Pola koping merupakan suatu kecenderungan dalam menginterprestasikan dan berrespon terhadap stres dengan cara tertentu. Proses koping dan hasilnya terhadap suatu stres 
dipengaruhi oleh pola koping seseorang. Pola koping dapat berdampak langsung pada emosi dan tindakan fisik seseorang, menghadapi peristiwa yang sangat menekan (Glanz K, Rimer B.K, and Viswanath K, 2008). Seorang narapidana selama di lapas mengalami stres dan tertekan karena proses kehilangan kemerdekaan, keluarga (anak, suami, bapa-mama), pekerjaan, suasana rumah, kesempatan, dan masih banyak kehilangan lainnya. Mekanisme koping yang efektif diperlukan untuk mengatasi rasa kehilangan ini.

Hasil penelitian terhadap perempuan yang berada di lapas menunjukkan lebih dominan pikiran dan perasaan negatif daripada pikiran dan perasaan positif. Orang dengan pikiran dan perasaan negatif dominan, berkembang menjadi psikologi negatif. Menurut Seligman dan Csikszentmihalyi, 2000, seorang manusia sebaiknya mengembangkan psikologi positif. Psikologi positif adalah karakter yang dikembangkan menjadi seorang yang berpengharapan, bijaksana, orientasi pada masa depan, berani, kehidupan rohani yang baik (spiritual). Psikologi positif berhubungan pula dengan karakter yang optimis, kuat, berguna dalam hidup, merasa dapat bekerjasama, meningkatnya perhatian. Beberapa studi menunjukkan bahwa ada hubungan antara penampilan diri yang positif dengan koping yang aktif(Lechner and Others, 2006; Kinsinger and others, 2006). Seorang narapidana penting mengembangkan psikologi positif, sehingga menjadi seorang yang berpengharapan, optimis, orientasi masa depan, berani, kuat, merasa berguna dalam hidup dan kehidupan rohani yang baik. Dengan demikian akan terbentuk koping yang aktif menghadapi stres di lapas.

Ada berbagai cara dalam intervensi stres menurut model transaksional stres dan koping. Upaya koping ditujukan untuk manajemen masalah dan pengaturan emosional. Untuk ini penting penampilan diri yang positif, merevisi tujuan, meningkatkan keyakinan spiritual dan selalu melakukan hal-hal positif. Seorang narapidana di lapas, penting mengembangkan pikiran dan perasaan positif, menentukan tujuan hidup baru selama berada di lapas menjalani hukuman, berpasrah kepada Tuhan dan selalu melakukan hal-hal positif yang bisa didapat di lapas. Seperti contoh ungkapan "mengapa kasus kami ini harus menjalankan hukuman secara murni, mengapa saya tidak dapat remisi dan urus pembebasan bersyarat? Kenapa yang lain bisa?'(P6). Partisipan ini masih berpikiran dan berperasaan negatif, tujuan berada di lapas belum jelas, kurang berpasrah. Ungkapan partisipan 11, " komunitas disini (lapas) situasinya menumbuhkan rasa sakit", atau "Saya sering menangis, menyendiri dan gampang tersinggung. Tuhan tidak adil terhadap saya, saya tidak berguna bagi keluarga" (P10). Partisipan 10 dan 11 ini perlu mengembangkan optimisme, menetapkan tujuan baru selama di lapas, berserah dan berdoa kepada Tuhan sesuai agama dan keyakinan serta terlibat dalam kegiatan positif yang dilaksanakan di lapas.

Perilaku seseorang berhubungan langsung dengan disfungsi emosional dan berpikir irasional. Hal ini diobati dengan mengubah pola pikir, dari negatif menjadi positif, diikuti oleh perubahan perilaku menjadi perilaku adaptif. Seperti yang 
disampaikan partisipan 7 "saya banyak diam dan suka marah-marah"; partisipan 40 " saya tidak bisa terima kalau diperintah"; partisipan 43, "sakit kepala terus dan leher tegang"; dan partisipan 48 "kadang saya tidak kuat dengan keadaan disini". Ada partisipan yang mengatakan " merasa takut luar biasa karena ditegor dengan suara keras"(P27). Partisipan 28 mengatakan "merasa tidak nyaman berada ditengah orang banyak karena tidak mengenal satu sama lain”. Pada kondisi ini perlu belajar mengidentifikasi pikiran yang melenceng dan merubah menjadi realistis akan mengurangi depresi dan meningkatkan koping adaptif (Carrico and others, 2005b). Pikiran positif menghasilkan kebahagiaan, sukacita, kesehatan serta kesuksesan dalam setiap situasi dan tindakan seseorang. Pikiran dan perasaan positif yang ditemukan dalam penelitian ini diungkapkan "berdoa kepada Tuhan karena Dia segala-galanya, Tuhan menyerati kita didalam setiap persoalan" (P46); "saya merasa senang dan bahagia" (P33); "senang teman yang bersifat terbuka sehingga tidak beban pikiran" (P21). Jika makin banyak narapidana berpikir positif seperti P21, P33 dan P46, dapat menularkan ke penghuni lapas lainnya sehingga semakin banyak narapidana perempuan yang sehat jiwa.

Menurut skema emosi Greenberg 2002, pikiran-pikiran yang ada bersamaan dengan emosi/perasaan yang timbul akan membentuk pengalaman emosi subyek, yang kemudian akan ditunjukkan dalam perilaku seseorang (Suyanta, Ekowarni Endang, 2012). Pikiran negatif tentang sidang yang tertunda, keluarga dan orang tua sakit, tidak bisa menelpon, tidak dibesuk dan bertemu keluarga, berpikir tentang lamanya vonis hukuman yang akan dijalani, tak ada uang, tidak dikunjungi anak dan suami, berbeban berat dalam hidup, banyak pikiran, pekerjaan setelah keluar lapas. Perasaan atau emosional negatif narapidana berupa stres, sedih, jengkel/benci, tidak senang/tidak nyaman, takut menghadapi hukuman, kecewa, marah, tidak adil, bosan, sakit hati akan menghasilkan respon tindakan tubuh negatif pula. Oleh karena itu pegawai lapas belajar tentang mekanisme koping yang efektif sehingga dapat mengarahkan narapidana untuk mempertahankan kesehatan jiwa.

Pengalaman hidup dalam penjara atau lapas sangat berat bagi seorang perempuan, khususnya yang berperan sebagai ibu rumah tangga. Menurut konvensi internasional seorang narapidana perempuan mengalami kekerasan karena mengalami penderitaan fisik (suhu kamar yang panas), seksual (pisah dari suami) dan psikologis (kehilangan kemerdekaan, pisah dari anak dan keluarga), termasuk ancaman tertentu (persidangan tertunda, vonis yang dijatuhkan), pemaksaan (mengikuti aturan dalam lapas seperti jam bertamu, kerja angkut air got), perampasan kemerdekaan di depan umum (hidup dalam lingkungan lapas saja, tidak boleh keluar lapas) dan dalam kehidupan pribadi (tidak bisa melakukan hoby, dll) (Wiwiek Afifah, 2013). Adanya beban ganda menyebabkan perlunya pembinaan warga lapas (narapidana) perempuan secara intensive. Sebaiknya dibagi dalam kelompok sesuai kasus pidana sehingga dapat terjadi sharing pengalaman, informasi, pengetahuan, dan terjadi saling menguatkan koping masing-masing (Rahmat, 2015). Terapi kelompok yang di padukan dengan terapi humor dan rekreasi dengan jadwal teratur dan 
pemimpin kelompok yang professional sangat baik. Dalam Keperawatan jiwa terapi kelompok bersifat kuratif sebagai sumber informasi, kembangkan harapan baru, berasas universal, senang jika membantu orang lain, koreksi hasil rekapitulasi kembali anggota keluarga inti, kembangkan tehnik-tehnik sosialisasi, perhatikan pada perilaku palsu, belajar antar pribadi, perkuat ikatan atau kesatuan dalam kelompok dan sebagai catharsis (pembersihan) ( Stuart , 2006).

\section{KESIMPULAN}

Seorang perempuan yang terpidana lebih banyak mengembangkan pikiran dan perasaan negatif, serta respon tindakan yang negatif pula selama berada di lapas. Hal ini memberi gambaran bahwa koping yang berkembang dalam diri narapidana perempuan lebih banyak belum efektif. Dengan demikian pendidikan kesehatan tentang pentingnya mengembangkan sikap optimis dalam menghadapi segala situasi atau persoalan, memberi efek respon koping efektif menghadapi masalah. Koping efektif terbentuk pula dari adanya support social (dukungan suami, keluarga, anak), psikologi positif, manajemen stres yang baik. Petugas maupun tenaga kesehatan di lapas, perlu mengembangkan kelompok-kelompok dengan kasus pidana sejenis untuk melaksanakan terapi kelompok demi menjaga dan mempertahankan kesehatan jiwa .

\section{DAFTAR PUSTAKA}

Kanwil Nusa Tenggara Timur. 2017. Sistem Database Pemasyarakatan Maret 2017. Kupang

Peraturan Menteri hukum dan Hak Asasi Manusia RI, Nomor 5 Tahun 2013 tentang Tata Tertib Lembaga Pemasyarakatan dan Rumah Tahanan Negara.

Rahmat Hi. Abdulah. "Urgensi Penggolongan Narapidana dalam Lembaga Pemasyarakatan" Fiat Yustisia Jurnal Hukum, Volume 9, Nomor I, JanuasriMaret 2015: 49-60

Meilina Clara Priscilla, 2013. Skripsi: Dampak Psikologis Bagi Narapidana Wanita yang Melakukan Tindak Pidana Pembunuhan dan Upaya Penanggulangannya. Malang: Universitas Brawijaya

Potter, Patricia; Perry, Anne Griffin, 2005. Buku Ajar: Fundamental Keperawatan, Konseo, proses dan praktik. Jakarta: Penerbit EGC

Gail W. Stuart, 2006. Buku Saku Keperawatan Jiwa. Jakarta: EGC

American Psychiatric Association (APA), 2016. Practice Gaudelines for the Psychiatric Evaluation of Adults. $3^{\text {rd }}$. USA: APA

Karen Glanz, Barbara K. Rimer, K. Viswanath, 2008. Health Behavior And Health Education Theory, Research, and Practice. $\quad 4^{\text {th }}$.EDITION. St. Fransisco: Jossey-Bass

Ekowarni Endang, Suyanta. "Pengalaman Emosi dan Mekanisme Koping Lansia yang Mengalami Penyakit Kronis". Jurnal Psikologi , Volume 39, no. 2, Desember 2012: 208-221 
Wiwik Afifah. "Perlindungan Hukum Bagi Perempuan Korban Perkosaan Yang Melakukan Aborsi“. DIH, Jurnal Ilmu Hukum Pebruari 2013, Vol. 9, No. 18: 93 - 109.

Corrico, A.W., and Others. "Cognitive Behavioral Stress Managementy Effects on Mood, Social Support, and a Marker of Antiviral Immunity are Maintained up to 1 Year in HIV-Infected Gay Men" Internasional Journal of Behavioral Medicine, 2005b, 12, 218-226

Kinsinger D.P., and Others. "Psychosocial and Sociodemographic Correlates of Benefit-Finding in Men Treated for Localized Prostate Cancer". Psychooncology, 2006, 15, 954-961

Lechner, S.C. and Others. "Curvilinear Associations Between Benefit Finding and Psychosocial Adjustment to Breast Cance" Journal of Clinical and Consulting Psychiatry, 2006, 74, 828-840

Seligman, M., and Czikszentmihalyi, M. "Positive Psychology: An Introduction". American Psychologist, 2000, 55(1), 5-14

ntt.kemenkumham.go.id Satuan Kerja di lingkungan kantor Wilayah NTT, Lapas Wanita Kelas III Kupang. Data narapidana Perempuan. Tanggal 13 Maret 2017 